\title{
ПУБЛІЦИСТИКА ЖУРНАЛУ «УНІВЕРСУМ» (1993-2018) ЯК ДІЄВИЙ ЧИННИК УТВЕРДЖЕННЯ УКРАЇНСЬКОЇ ДЕРЖАВНОСТІ
}

\author{
Вікторія Романчук \\ Всеукраӥнський журнал політології, футурології, економіки, науки та культури \\ «Універсум», а/с 2994, 79017, Львів, Украӥна \\ e-mail:viktoriya.romanchuk7@gmail.com \\ https://orcid.org/0000-0003-1594-3995
}

У статті проаналізовано публіцистику журналу «Універсум», яка насамперед присвячена різноманітним проблемам утвердження і побудови української державності й доведено, як на сторінках видання відомі журналісти, вчені, військовики аналітично, у яскравій публіцистичній формі ретельно досліджували соціальну дійсність України, суспільно-політичні аспекти різноманітних явищ життя. Автор вважає, що публіцистика «Універсума» - це своєрідний сплав науки, журналістики і красного письменства, який дозволяє всебічно осмислити ту чи іншу порушену проблему, дати зважену оцінку тому чи іншому факту. Водночас цей різновид творчості дозволяє глибоко й об’єктивно відчути та зрозуміти ставлення суспільства до справедливості, до творення громадського ідеалу.

Ключові слова: сучасна українська публіцистика, журнал «Універсум», українська державність.

Вступ. Державна стратегія вимагає зорієнтованості сучасної освіти на формування національно свідомої і духовно багатої особистості, зумовлює потребу вивчення сучасної публіцистики, яка є могутнім джерелом морального, національного, патріотичного виховання молоді. Журнал «Універсум» по суті є тим виданням, що робить вагомий внесок у розвиток української журналістики. Суспільно-політична проблематика журналу 1991-2018 років не втратила актуальності. Грунтовним публіцистичним дослідженням багатьох тем притаманний прогностичний характер, індивідуальність та унікальність поглядів і думок. Творчий доробок публіцистів «Універсума» - це важливий внесок у вивчення чвертьстолітньої історії сучасної Української держави.

Постановка проблеми. 3 появою на політичній мапі світу суверенної України, перед українськими ЗМІ виникла проблема нових авторів, розробки нових методів подачі матеріалів, які б допомагали громадянам осмислювати сучасний світ, сформувати в їхній свідомості реалістичну модель сьогодення. Журналістика наполегливо шукала ефективний інструментарій для втілення своїх амбітних планів. Одним

(C) Романчук B., 2019

Наукове рецензування і рекомендація до друку - проф. Кость С. А. 
3 дієвих засобів творення державності стала публіцистика, приваблюючи читачів логікою, переконливою аргументацією, історичними екскурсами, фаховим аналізом, залученням до діалогу авторитетних фахівців, використанням багатющих можливостей мови.

Мету статті вбачаємо в тому, щоб з'ясувати основні проблеми, що їх висвітлювали і аналізували публіцисти на сторінках «Універсума» впродовж 1993-2018 років, простежити за динамікою політичного, економічного, культурного, воєнного та економічного дискурсу, рівень фаховості аналізу означених проблем.

Виклад матеріалу. Публіцистика - складний різновид журналістської та літературної праці. В історії людства саме публіцистика не раз опинялася в епіцентрі уваги всіх прошарків населення. Наприкінці 80-х - на початку 90-х минулого століття століття саме пубіцистичні твори письменників, журналістів, економістів, політиків перевершили всі рекорди популярності серед читачів на теренах СРСР.

В українському журналістикознавстві досі не стихають дискусії про роль публіцистики. Адже вона не тільки віддзеркалює події та факти, але й порушує складні соціальні проблеми, формує громадську думку, визначає вектори національної ідентичності, моралі. Оскільки з бігом часу постають нові питання, то актуальність того чи іншого явища або проблеми втрачається. Одначе твори визнаних публіцистів можуть і далі спонукати суспільство до розв'язання нових завдань.

Публіцистика журналу «Універсум» - це, без перебільшення, своєрідна духовна скарбниця, в якій упродовж двадцяти п'яти років активної творчої праці редакції та авторського колективу зібрані надзвичайно цінні думки, гіпотези, оригінальні погляди на складні суспільні явища, оприлюднені ексклюзивні результати досліджень соціальних, економічних і політичних процесів, в яких чітко простежується прагнення знайти оптимальні способи розв'язання назрілих проблем та отримати відповіді на запитання, котрі постають в процесі побудови Української держави.

Публіцистичним статтям в журналі притаманна аналітична глибина, грунтовна насиченість фактологічним матеріалом, для них характерні яскравість і доступність стилю, вони водночас наукові та популярні. Будівельний матеріал текстів, підібраний уміло і поданий майстром слова об'єктивно. Такі відомі публіцисти, як Леонід Сотник, Леонід Капелюшний, Віталій Карпенко, Володимир Вітковський, Олег Романчук та інші ефективно використовували різноманітні способи впливу на аудиторію. Приклади блискучої політичної, економічної, наукової, військової публіцистики неодноразово демонстрували доктори економічних наук Юрій Саєнко, Степан Вовканич і Віктор Борщевський, доктори фізико-математичнх наук Леонід Шульман і Анатолій Свідзинський, доктор хімічних наук Октавіан Ксенжик, доктор медичних наук Володимир Войтенко, доктор філологічних наук Василь Лизанчук, військовий аналітик Петро Костюк та інші.

Автори журналу з державницьких позицій аналізують та інтерпретують різноманітні події в українському суспільстві та в світовому контексті, фахово досліджують політичні процеси в державі й за кордоном, роблять влучні прогнози, акцентують на конечності розв'язання тих чи інших конкретних суспільних проблем (соціальних, політичних, історичних, наукових, освітніх, стратегічних), вкрай важлививих для успішного вирішення завдань державотворення. Більшості матеріалів притаманне системне й аналітичне бачення та розуміння проблем у поєднані з публіцистичною гостротою викладу. 
Чільне місце на сторінках часопису займає публіцистика найрізноманітнішої тематики: економічної, соціальної, політичної, мілітарної. У публіцистиці «Універсума» вирізняється тенденція тлумачити ідейні та суспільні погляди насамперед для утвердження державницьких устремлінь народу з метою побудови модерної України.

Особливим публіцистичним елементом часопису, надзвичайно важливою його складовою є «Слово редакційне». Саме по цій рубриці, як своєрідному інтерпретатору реалій сьогодення, зрештою, судять насамперед про рівень видання. Ця рубрика - яскравий приклад використання аналітичного жанру. На неї зважають політики, цитують журналісти інших засобів масової інформації. Це і гостра публіцистична стаття, і водночас ретельне аналітичне дослідження або фаховий коментар. «Слову редакційному» в інтерпретації «Універсума» завжди притаманна чіткість і доступність позиції, висловленої автором . Рубрику вирізняє оригінальний, сміливий підхід і неповторний авторський стиль - саме те, що притаманне публіцистиці найвищої проби.

Тексти цієї рубрики є взірцем високої майстерності публіциста, служать своєрідним еталоном якості журналу. Розуміючи, що редакційну статтю оцінюватимуть не лише читачі, а й набагато прискіпливіше колеги-журналісти з інших видань, редакція «Універсума» особливо відповідально ставиться до публічних виступів у цій рубриці. Гостро реагуючи на болючі виклики сьогодення, публіцисти видання прагнули якомога дохідливіше пояснити складні політичні та культурні явища, переконливо обгрунтувати, чому вони виникли, які причини сприяли тим чи іншим подіям, а головне - спрогнозувати, який результат чекає на процес чи явище. Такий підхід можна назвати моделебудівним, він дає змогу зрозуміти перспективу майбутнього країни та суспільства загалом.

Поштовхом до написання флагманських матеріалів «Універсума» ставали найрізноманітніші приводи: передусім державне будівництво, політика, культура, суспільні відносини, мовне питання, військо, економіка, наука тощо. При цьому йдеться не лише про відгук на злободенну тему. Як правило, пропонуються добре аргументовані кардинальні рішення, виважене тлумачення проблем, які хвилюють суспільство, а ще обгрунтована критика на адресу влади. Серед явищ і подій, що їх обговорювали автори, немало таких, які втратили свою першорядність, одначе цінність їхня непроминальна - вони є історичним свідчення різноманітних процесів у державі, які призвели до нинішніх результатів у супільстві. Підтвердження того, що грунтовним дослідженням багатьох тем суспільно-політичної проблематики притаманний прогностичний характер, може стати аналіз найхарактерніших публіцистичних матеріалів видання.

Одним із найяскравіших та найактивніших авторів журналу був публіцист, журналіст, політолог, член редколегії Леонід Сотник. Він змушував читача аналізувати, думати, ретельно зважувати побачене й почуте в статтях різної тематики. Публіцист ніколи нічого не диктував і не нав'язував. Він сам шукав, сумнівався, сперечався. Й цим і нині цікавий для нас. Скажімо, Леонід Сотник свого часу зробив цілком слушний висновок: «Україну врятує та політична сила, яка не на словах, а на ділі забезпечить надходження в державу широкого потоку іноземних інвестицій». Він добре розумів, що для реалізації цього проекту треба забезпечити контроль за використанням цих інвестицій, знищити корупцію, створити належний інновацій- 
ний клімат тощо. А ще потрібна політична сила, яка б могла реалізувати поради публіциста. Яка, на жаль, досі в Україні відсутня.

У часописі сформувався цілий цикл історико-філософських есеїв, які написала небайдужа людина. Леонід Сотник нестандартно розповідав про реальні події і про те, що підказувала йому совість, великий життєвий та журналістський досвід. I про «білоруський синдром», і про «уроки чеченської війни», і про «міста російської слави», і про те «кому потрібна влада в Україні» тощо.

Більш ніж промовисті назви багатьох творів цього публіциста: «Маразм як чинник державотворення в Україні», «Хочеш мати раба - забери у нього мову», «Політична стабільність як танок на дроті», «Попіл минулого стукає у груди сьогодення»...

Леонід Сотник популярно роз'яснював «від якої спадщини нам варто відмовитись» [10]: «Навіть заповзяті прихильники економічного союзу між двома нашими державами починають усвідомлювати, що комунофашисти, які правлять у Росії, можуть поставити хрест на всіх і всіляких реформах. За таких умов економічний альянс з Росією смерті подібний».

У нотатках «Уроки чеченської війни» [11] Леонід Сотник продемонстрував глибоку обізнаність з предметом дослідження. Його аналіз і сьогодні на часі: «Нинішня кризова політична ситуація в Росії (іiі аналіз - тема окремої статті) свідчить про те, що федерація аж ніяк не може обійтись без образу зовнішнього ворога. Цей образ завжди виручав iï. А кращого ворога, ніж Україна, важко собі й уявити. Тому я, наприклад, не здивуюсь, коли за допомогою п’ятої колони російським урядовим структурам вдасться спровокувати такий собі конфлікт десь у районі «города русской славы Севастополя» і, звичайно ж, звинуватити у тому нашу державу. А потім підніметься не те що хвиля - цілий шторм. I продемонструє він непорушну єдність російського народу».

Ще два десятиліття тому Леонід Сотник усвідомив небезпеку культурно-історичних спекуляцій з боку Росії. Тоді ще ніхто не говорив про культуру та історію як напрочуд ефективний засіб ведення інформаційної війни. Тож такі дослідження як «Міста російської слави» [12] і «Пушкін в ореолі легенд, або синдром національного психозу» [13] стали переконливим підтвердження небезпечних проявів культурної експансії Москви.

Чудово розуміючи, що мовне питання є однією з передумов поступального розвитку нації, Леонід Сотник зазначав: «Інформаційне поле - то поле битви за вільну Україну. Але ж на ньому можна вкрити своє ім’я і славою, і вічною ганьбою» [14].

У своєму останньому публічному виступі «Прощання з XX століттям» [15] Леонід Сотник ретельно аналізував політичні події XX століття, зокрема розпад колоніальної системи, здобуття незалежності тими народами, які (серед них й Україна) із запізненням взялися утверджуватись серед державних націй. Думки публіциста, оприлюднені на зламі тисячоліть, і сьогодні допомагають краще зрозуміти навколишній світ: «Якщо ми не втратимо незалежності і сповна використаємо другий шанс, який нам подарувало XX століття, то у столітті XXI нас чекає величезна, тяжка робота. Нам треба перебудувати не тільки економіку, суспільний лад, але й самих себе. Ми можемо і мусимо згуртуватись у політичну націю».

Доктор економічних наук, завідувач відділу соціальної експертизи Інституту соціології НАН України Юрій Саєнко в дослідженні «Комунізм - це хвороба бідних і рабів» [8] докладно аналізує феномен совєтського комуністичного рабства - рівно- 
сті у бідності й злиднях у статті: «Класичний раб мав господаря і Бога. В совєтському виконанні вони обидва де-факто раби. Бо обидва позбавлені власності на себе і на будь-що, що б давало змогу бути господарем власної долі. Це була тотально рабська держава, яка в дійсності складалася з самих лише рабів... Раб не поважає нікого і ніщо. Для нього не існує законів. Страх замінює закони. Раба змушують коритися волі гнобителів. Раб боїться чужого, нового і незнайомого. - інакшого... Трагедія в тому, що українська людина з совєтською рабською свідомістю опинилася в уже не зовсім рабській ситуації, де треба мати особисту волю до життя, власні орієнтири, вміння вибору і особисту відповідальність. А українська совєтська людина не знає, що таке вибір, не вміє його робити... Українська людина самого кінця XX століття опинилася у розірваному життєвому просторі з розірваною свідомістю. Розірвано політичний, економічний, соціальний, інтелектуальний, соціокультурний та інформаційний єдиний простір».

У статті «Країна втрачених шансів» [9] Юрій Саєнко блискуче проаналізував ситуацію, в якій опинилась Українська держава: «1991 року утворилася незалежна Україна, й пішла серія втрачених шансів. По-перше, ми помилково роззброїлися. По-друге, в Криму залишився російський флот, джерело напруги й сепаратизму. По-третє, у державі не відбулася люстрація. <...> Втрата шансів привела нас до деструктивності, аморфності, а звідси - до деградації соціального здоров'я. <...> На мій погляд, єдиний шанс України стати модерною державою - це зміна поколінь. <..> Якщо нинішня управлінська еліта не здасть своїх позицій, а в молодого покоління забракне сил, щоб витиснути їх із крісел, то можна $з$ гіркістю констатувати - в України немає майбутнього».

Традиційно безкомпромісний в оцінках навколишньої дійсності доктор медичних наук Володимир Войтенко. Більш ніж промовиста назва однієї з його статей «Аморальна влада приречена, але у могилу вона завжди тягне живих» [1]: «Система суспільного лицемірства за часів радянщини трималася на соціалістичних і комуністичних гаслах, а нині вона спирається на «демократію», «реформи» $\mathrm{i}$ «розбудову держави». Але - дозволю собі послатися на великого реаліста Йозефа Швейка - «усе це г...на варте». Бо кількість жебраків, яких я щодня бачу по дорозі з дому на роботу (і з роботи додому) не зменшується, а зростає».

У статті «Українська ідея» [2] Володимир Войтенко звертає увагу на те, що держава і народ потребують термінової соціальної реабілітації, яка «можлива за умов зустрічного руху народу до влади і влади до народу». Вчений акцентує, що найбільших успіхів у XX ст. домоглися країни, суспільство в яких спиралося на чотири засадничі позиції: християнську мораль, соціал-демократичну ідеологію, природоохоронну (зелену) етику і комп'ютеризацію виробництва та освіти. Аргументація Володимира Войтенка образна, чітка, переконлива: «Україна у XXI сторіччі має тягти за собою вантажі іншого гатунку. Це, по-перше, деморалізований народ, схильний водночас і до анархії, і до безмежного конформізму («змученості» на тюремному жаргоні). Це, по-друге, інтелігенцію, яка значною мірою втратила роль духовного стрижня нації, перетворившись на посередника між народом і номенклатурою. Це, по-третє, сама номенклатура, більша частка якої в радянські роки не мала розуму й совісті, а нині позбулася ще й страху. Найнебезпечнішим тягарем $є$ найвищі державні посадовці, які народу не бачать, інтелігенцію зневажають, а номенклатури бояться». 
У статті «Українська реконкіста: соціально-культурні наслідки державної безпеки» [6] публіцист Олег Романчук акцентує увагу на потребі створення ефективної влади, яка б відштовхувалася чи навіть базувалася на національних пріоритетах. Натомість український провід сконцентрував свою увагу не на політиці держави, а на накопиченні власних статків. «Він (істеблішмент) повсякчас демонструє світові брак політичної волі, захланність і аморальність, він позбавлений не тільки розуміння політичної культури, а й розуміння політичної культури взагалі». Роздуми публіциста справді непроминальні: «Нинішня політична боротьба в Україні - це не боротьба за комунізм чи капіталізм, за демократизм чи тоталітаризм, а боротьба за існування Української держави в принципі. <...> За благеньким національним риштованням залишилась незалежна за формою, але по суті перефарбована совєтчина. $<$..> Спостерігаючи за тим, хто і як порядкує сьогодні у вищих владних ешелонах держави з вивіскою «Україна» (Азаров, Арбузов, Богатирьова, Єфремов, Калінін, Колесников, Могильов, Саламатін, Табачник, Тигіпко, Чечетов, Янукович та ін.), приходиш до висновку, що видатний англійський політик, прем'єр-міністр Великобританії, етнічний єврей Бенджамін Дізраелі мав рацію, наголошуючи, що «національне питання - ключ до всіх загадок світової історії. Національна належність - єдина істина». У ток-шоу після прем'єри фільму «ДНК-портрет нації» (листопад 2012 року) взяв участь Давід Мільман, помічник головного рабина України. Він акцентував, що «є націоналістом, а націоналізм - це основа національної ідеї. Без поваги до себе жодна країна не може існувати. <..> Бо тільки поважаючи себе, можна поважати інші народи».

2011 року Леонід Капелюшний опублікував на сторінках «Універсума» блискучу за стилем й глибиною аналізу статтю «У нашому домі йде реставрація імперського режиму за ширмою декларативного суверенітету» [3]: «Кремль провів блискучу операцію із дискредитації Помаранчевої революції і самого Ющенка, всіляко сприяв гризні між лідерами демократичного крила, які врешті-решт не тільки стали посміховиськом для всього світу, а й виставили на сміх нашу державу. П'ята колона в Україні виконала найважчу і найскладнішу роботу - дезорганізувала керованість державою і порушила суспільне порозуміння між українськими громадянами. Не між українцями - а поміж громадянами країни. $<\ldots>$ У жодному регіоні країни так нищівно і безжально не експлуатується людина, так мало не важить людське життя i гідність, як в Донбасі. Феномен тамтешнього електорату не у фанатичній відданості Партії регіонів, а в абсолютній залежності людей від роботодавців, які поводяться як пахани. I ось цей стиль кримінальної корпорації дони принесли в парламент, а відтак нав'язують його і всій Україні. < .. > Щодень у ефірному просторі України гарцюють вже не проросійські провокатори, а російські політичні технологи і політики, які витирають лапті об українські національні інтереси < .. > Мета їхня, як шило у мішку - відокремлення, хоч скальпелем, хоч сокирою, Лівобережжя із прирощенням цього краю до Росії. Треба визнати блискучою роботу росіян із повернення України у сферу впливу РФ без жодного пострілу і синця. Я певен, цю операцію будуть вивчати спеціальні служби усього світу як зразкову. Нам наразі лишається зрозуміти не тільки що відбувається, а й що буде із Україною».

Доктор хімічних наук Октавіан Ксенжек у грунтовній статті «Ще не вмерла Україна...» [4] поставив чіткий діагноз: «Україна важко хвора. Вона терпить від цілого спектра недуг різної природи: генетичних, психічних, соматичних. $<\ldots>$ Явний 
імунодефіцит відносно реліктів комуністичної ідеології і досить бурхливої активності її нинішніх носіїв, шизофренічний стан національної свідомості, її роздвоєння у фундаментальних питаннях, від яких залежить саме існування України, таких, наприклад, як ставлення до колишньої метрополії, мовна проблема і т.д. Нарешті, Україна просто фізично вимирає». Учений резюмує: «Не маючи власної стратегії, Україна всі роки незалежності діяла, в основому, за принципом «як би зробити все по-новому, щоб залишилося все по-старому»... Отримавши формальну незалежність, ми, по суті, не знаємо, для чого вона нам потрібна». Є деяка надія вийти з цього складного становища, «але за умови, що нація докладе величезних, незвичних для неї зусиль, щоб нарешті навчитись чітко розуміти дійсний і навіть прихований сенс всього того, що робиться в її країні, і діяти відповідно».

Стаття Олега Романчука «Від кризи соціального розвитку до соціального вибуху?» [7] спонукає до роздумів над ймовірністю соціального вибуху в Україні: «Умови соціального вибуху виникають тоді, коли центральні механізми внутрісистемної регуляції не можуть або не хочуть зробити необхідні зміни в організації суспільства. Це відбувається тоді, коли інтереси правлячих груп держави і тих груп, що володіють власністю (основними ресурсами суспільства), не співпадають 3 потребами всієї системи - інтересами більшості членів суспільства. <..> Внутрішні й зовнішні протиріччя в Українській державі настільки загострились, що для її подальшого існування нагальне розв'язання критичних задач стало життєво необхідним».

Мирослав Маринович, відомий правозахисник, проректор УКУ, категорично стверджує: «Україна або модернізується - або її взагалі не буде» [5].

Висновки. Завдання сучасної журналістики полягає в тому, аби разом 3 експертами, науковцями шукати вихід з кризової ситуації. «Універсум» намагався і намагається виконувати це завдання не лише як періодичне видання, але і як своєрідний наставник, який пояснює складні політичні та культурні явища, обгрунтовує причини їх виникнення, а головне - точно передбачає результат. Позицію журналу можна назвати моделебудівною, яка вимальовує перспективу майбутнього країни та суспільства.

«Універсум» - це унікальна журналістська лабораторія. Автори не просто констатують проблему та ситуацію, а пояснюють їхні причини та витоки на основі грунтовного аналізу, в результаті ретельних розрахунків і спостережень за соціальними та політико-економічними процесами, залучаючи для обговорення визнаних спеціалістів. При цьому журнал прагне підштовхнути читачів до ухвалення правильних висновків, до усвідомлення важливості визначення пріоритетів.

Аналітична публіцистика на сторінках «Універсума» відображає особливості та проблеми творення політичного, економічного життя i, що сьогодні вкрай актуально, військової сфери. Подача фактів, подій, явищ у реальному, а не завуальованому контексті; передбачення результату - основні ознаки публіцистики часопису.

Оприлюднені в журналі тексти дають широку, насичену маловідомими, а частіше й зовсім не відомими фактами панораму нашого буття - поступу і поразок, задумів і розчарувань, сподівань і невідворотних реалій. Це неоціненний матеріал для історика, філософа, політолога, економіста, соціолога, правника, культуролога, для науковців та студентства, врешті для всіх, хто не байдужий до політико-економічних, соціально-культурологічних, науково-футурологічних проблем. 


\section{REFERENCES}

1. Войтенко В. Аморальна влада приречена, але у могилу вона завжди тягне живих / В. Войтенко // Універсум. 2001. №3-4. С.29-34.

2. Войтенко В. Українська ідея / В. Войтенко // Універсум. 2007. №9-10. С.1-3.

3. Капелюшний Л. У нашому домі йде реставрація імперського режиму за ширмою декларативного суверенітету / Л. Капелюшний // Універсум. 2011. №1-2. С.19-35.

4. Ксенжек О. Ще не вмерла Україна... / О. Ксенжек // Універсум. 2007. №11-12. C.5-15; №1-2, 2008. C.4-11.

5. Маринович М. Україна або модернізується - або її взагалі не буде / М. Маринович // Універсум. 2018. №3-4. С.1-2.

6. Романчук О. Українська реконкіста соціально-культурні складники національної безпеки / О. Романчук // Універсум. 2013. № 7-8. С.6-29.

7. Романчук О. Від кризи соціального розвитку до соціального вибуху? / О. Романчук // Універсум. 2014. № 1-2. С.1-3.

8. Саєнко Ю. Комунізм - це хвороба бідних і рабів / Ю. Саєнко // Універсум. 1999. № 3-4. C.24-28.

9. Саєнко Ю. Країна втрачених шансів / Ю. Саєнко // Універсум. 2007. № 5-6. С.1-3.

10. Сотник Л. Від якої спадщини нам варто відмовитись / Л. Сотник // Універсум. 1994. №3-4. C.16.

11. Сотник Л. Уроки чеченської війни / Л. Сотник // Універсум. 1996. №9-10. С.14-16.

12. Сотник Л. Міста російської слави / Л. Сотник // Універсум. 1996. №11-12. С.4-9.

13. Сотник Л. Пушкін в ореолі легенд, або синдром національного психозу / Л. Сотник // Універсум. 1999. №5-6. С.35-37.

14. Сотник Л. Хочеш мати раба - забери в нього мову / Л. Сотник // Універсум. 1999. №7-8. C.14-16.

15. Сотник Л. Прощання з ХХ століттям / Л. Сотник // Універсум. 2001. №7-10. C. $81-88$ 


\title{
PUBLICISM ON THE PAGES OF THE UNIVERSUM MAGAZINE (1993-2018) AS AN EFFECTIVE FACTOR OF THE CONSOLIDATION OF THE UKRAINIAN STATE
}

\author{
Viktoriya Romanchuk \\ The all-Ukrainian Journal of Political Science, Futurology, Economics, \\ Science and Culture "Universum», \\ Box 2994, 79017, Lviv, Ukraine \\ e-mail: viktoriya.romanchuk7@gmail.com \\ https://orcid.org/0000-0003-1594-3995
}

In the article there is analyzed the publicism on the pages of the «Universum» magazine, which primarily deals with the various problems of the establishment and construction of the Ukrainian statehood. In the article it is shown and proved that the well-known journalists, scientists as well as the military personnel, in an analytical and in a bright journalistic form have thoroughly investigated the social reality of Ukraine and the socio-political aspects of the various life phenomena.

The author believes that the publicism of the «Universum» is a kind of alloy of science, journalism and literature that allows us to comprehend the important problems from various sides and thus to give a weighted assessment of some facts. At the same time, this kind of creativity allows us to feel and understand the attitude of the society towards the justice and towards the creation of the public ideal in a fair and objective way.

Key words: modern Ukrainian publicism, «Universum» magazine, the Ukrainian statehood. 